\title{
Wpływ koncepcji behawioralnych na współczesne systemy resocjalizacji instytucjonalnej
}

\begin{abstract}
Ambrozik Wiesław, The impact of the behavioral approach on the contemporary systems of institutional rehabilitation [Wpływ koncepcji behawioralnych na współczesne systemy resocjalizacji instytucjonalnej]. Interdyscyplinarne Konteksty Pedagogiki Specjalnej, nr 2, Poznań 2013. Pp. 9-23. Adam Mickiewicz University Press. ISBN 978-83-232-2594-2. ISSN 2300-391X.

This article presents the significant impact of behavioral concepts on how the contemporary theory and practice of social rehabilitation develops. However, it is noteworthy that even behaviorism, despite its popularity, did not manage to overcome the age-old juridical and criminological approach to prevention and social rehabilitation.
\end{abstract}

KEY WORDS: Behaviorism, system of prevention and social rehabilitation, token economy, progressive system

To, że najbardziej znaczący wpływ na rozwój współczesnej myśli i praktyki pedagogicznej, a w tym również na mieszczące się w jej ramach koncepcje oddziaływań kompensacyjno-opiekuńczych i profilaktyczno-resocjalizacyjnych, odegrał behawioryzm, nie potrzeba nikogo dziś przekonywać. Przeniknął on właściwie wszystkie dziedziny pedagogiki i trwa w niej po dzisiejsze czasy. Kierunek ten zadecydował też o strukturze i funkcjonowaniu systemu wychowania rozpatrywanego zarówno w płaszczyźnie ogólnocywili- 
zacyjnej, jak i narodowo-państwowej, lokalnej czy też instytucjonalnej. Znajdujemy go również u podstaw struktury i funkcjonowania większości systemów resocjalizacyjnych, wśród których wprawdzie znaleźć można cały szereg rozwiązań szczegółowych, nawiązujących często do innych koncepcji teoretycznych, jednak zasadniczo budowanych na przesłankach behawioralnych. To właśnie koncepcja behawioryzmu wniosła do teorii i praktyki wyjaśniania istoty procesu wykolejenia społecznego i przestępczego oraz do rozwoju teorii i praktyki postępowania resocjalizacyjnego fundamentalne jak pisze B. Urban - założenia świadczące o „środowiskowych źródłach zachowań; o tym że zewnętrzne bodźce wyzwalają reakcje (zachowania), a reakcje pozytywnie wzmacniane utrwalają się, reakcje niewzmacniane są zapominane, mechanizmy uczenia się (oduczania) dotyczą wszelkich zachowań, a typologia i moralna ocena zachowań według dobra i zła jest rzeczą wtórną, uzależnioną od społecznych (relatywnych) systemów wartości"1. Oto w zasadzie cała kwintesencja behawioryzmu stanowiąca dziś o kształcie wielu systemów resocjalizacji zarówno nieletnich, jak i dorosłych przestępców. Swoją powszechność i popularność kierunek ten zawdzięcza między innymi temu, że wyrósł na fali krytyki psychoanalitycznych form terapii, postrzeganych $\mathrm{w}$ świetle nagromadzonych doświadczeń jako oddziaływania mało skuteczne i często przypadkowo ulegające remisji (to główny nurt krytyki H.J. Eysenka i jego zwolenników). Innym formułowanym wobec psychoanalizy zarzutem było to, że zbyt często koncepcja ta koncentrowała się na głęboko ukrytych mechanizmach osobowościowych, do których sięganie nie zawsze było potrzebne i uzasadnione, a nie na interakcjach jednostki z jej bezpośrednim środowiskiem życia jako źródłem określonych zachowań oraz nie na poszukiwaniu w tymże środowisku takich bodźców i manipulacji, na które poddawana terapii jednostka będzie skutecznie reagowała, wzmacniając (poprzez uzyskiwane

${ }^{1}$ B. Urban, Pedagogika resocjalizacyjna w strukturze nauk społecznych, [w:] S. Palka (red.), Pogranicza pedagogiki i nauk pomocniczych, Wyd. Uniwersytetu Jagiellońskiego, Kraków 2004, s. 173. 
nagrody) zachowania społecznie akceptowane, a wygaszając (na skutek otrzymywanych kar) te spośród nich, które tej akceptacji nie uzyskują. Każde bowiem zachowanie, w świetle podejścia behawioralnego, jest bardziej związane $\mathrm{z}$ doświadczaniem i przetwarzaniem przez rozwijającą się jednostkę elementów otaczającego ją środowiska niż efektem dziedziczenia czy też zachodzących w wyniku rozwoju jakościowych przemian ${ }^{2}$. W związku z tym, że i wszelkie zaburzenia w zachowaniu się są wyuczonymi reakcjami na określone bodźce (sytuacje) albo też z uwagi na to, że występujące zaburzenia są konsekwencją braku określonych wzmocnień społecznych, to - zdaniem K. Pospiszyla - przed terapią behawioralną stoją trzy następujące cele:

1. Konieczność wyrównania wszelkich braków w zachowaniu się, powstałych wskutek rozmaitych niedostatków czy niedoborów wzmocnień.

2. Konieczność wygaszenia niewłaściwych form zachowania przy równoczesnym wzmacnianiu reakcji pożądanych społecznie.

3. Konieczność wzmocnienia kontroli nad zachowaniami własnymi, tak ażeby nie wystąpiły reakcje społecznie niepożądane ${ }^{3}$.

Zarysowane tu podstawowe założenia podejścia behawioralnego zaowocowały w teorii i praktyce resocjalizacyjnej odpowiednimi modelami uprawiania diagnozy oraz terapii postępowania korekcyjnego. I tak, przedmiotem diagnozy behawioralnej poprzedzającej postępowanie resocjalizacyjne stają się przede wszystkim "zachowania antyspołeczne, a ściślej rzecz biorąc związki zachodzące między czynnikami te zachowania poprzedzającymi (pojmowane jako ich bodźce) a wspomnianymi zachowaniami antyspołecznymi

2 Por. K. Pospiszyl, Resocjalizacja. Teoretyczne podstawy oraz przykłady programów oddziaływania, Wyd. Akademickie "Żak”, Warszawa 1998, s. 42-43; B. Urban, Zaburzenia w zachowaniu i przestepczość młodzieży, Wyd. Uniwersytetu Jagiellońskiego, Kraków 2000, s. 54-58; K. Hurrelmann, Struktura społeczna a rozwój osobowości, Wyd. Nauk. UAM, Poznań 1994, s. 23-26.

${ }^{3}$ K. Pospiszyl, dz. cyt. s. 44-45. 
(późniejszymi, rozumianymi jako ich reakcje)". Postrzeganie przy tym źródeł owych zachowań różni się jednak od ujęcia psychodynamicznego, które poszukiwało ich głównie w interakcjach jednostki z innymi osobami. Tutaj obszarem tym staje się przede wszystkim praktyka, w której poprzez toczące się w niej procesy uczenia się (warunkowania klasycznego, warunkowania instrumentalnego lub uczenia się poprzez obserwację i naśladownictwo) jednostka przyswaja sobie pożądane lub niepożądane zachowania4. Stąd też w terapii behawioralnej nie ma potrzeby wnikania w złożone psychologiczne mechanizmy generujące zachowania jednostki, które zresztą bardzo często są już swoistymi artefaktami, a jedynie poszukiwanie takich nagradzających, względnie karzących bodźców, dzięki oddziaływaniu których zachowania pożądane będą wzmacniane i utrwalane, a reakcje niepożądane wygaszane i zapominane ${ }^{5}$. $W$ praktyce resocjalizacyjnej często bowiem mamy do czynienia z sytuacjami, kiedy oto odnotowujemy wystąpienie $u$ jednostki zachowań niepożądanych, których źródłem pozostają bodźce zaistniałe znacznie wcześniej albo też których, bez względu na czas ich powstania, nie można było przewidzieć czy też nie można już usunąć. Powstałe w ten właśnie sposób i utrwalone przez jednostkę drogą procesu uczenia się zachowania niepożądane mogą zostać usunięte albo poprzez odpowiednio dobrane nowe bodźce wyzwalające zachowania pożądane lub wygaszające zachowania nieakceptowane albo poprzez wzmacnianą autokontrolę nad zachowaniami własnymi eliminującymi zachowania niepożądane. To jednak, czy proces ten powiedzie się, zależy od wielu czynników, których wykaz, w postaci podstawowych twierdzeń określających „prawdopodobieństwo wystąpienia reakcji, odporności na wygaszanie, generalizacji bodźca i reakcji”, znajdujemy w klasycznym już dziś opracowaniu A. Malewskiego. Oto te twierdzenia:

4 B. Urban, dz. cyt., s. 56.

${ }^{5}$ Por. L. Pytka, Pedagogika resocjalizacyjna. Wybrane zagadnienia teoretyczne, diagnostyczne i metodyczne, Wyd. Akademii Pedagogiki Specjalnej, Warszawa 2000, s. 129. 
1. „Prawdopodobieństwo występowania reakcji wzrasta wraz ze wzrostem wartości, częstości i regularności nagród otrzymywanych w następstwie tego rodzaju reakcji [...].

2. Jeżeli jakaś nagroda jest często powtarzana w krótkim okresie czasu, to każda następna nagroda tego samego rodzaju w coraz mniejszym stopniu zwiększa prawdopodobieństwo wystąpienia nagradzanej reakcji [...].

3. Nagrody opóźnione są mniej skuteczne dla zwiększenia prawdopodobieństwa wystąpienia nagradzanych reakcji aniżeli nagrody bezpośrednie - przy czym im bardziej opóźnione, tym mniej skuteczne [...].

4. Gdy powtarzanie jakiejś wyuczonej reakcji nie przynosi żadnych nagród, prawdopodobieństwo występowania tej reakcji stopniowo słabnie [...].

5. Dana reakcja jest bardziej odporna na wygaszanie, tzn. będzie ona dłużej występowała bez nagradzania, gdy przy pozostałych niezmiennych w ciągu poprzednich doświadczeń

a) więcej razy wystąpienie tej reakcji było nagradzane;

b) na jedną próbę przypadała większa nagroda;

c) osobnik częściej stykał się z nagradzaniem nieregularnym, czyli nagradzaniem tylko niektórych zachowań tego samego rodzaju;

d) krótszy okres czasu upłynął od otrzymania ostatniej nagrody;

e) reakcja została wyuczona we wcześniejszym okresie życia [...].

6. Nagradzanie danej reakcji przy określonym zespole bodźców zwiększa prawdopodobieństwo występowania tej samej reakcji nie tylko przy tym samym, ale również przy podobnych zespołach bodźców [...].

7. Przy pozostałych niezmiennych nagradzanie określonej reakcji przy danym zespole bodźców tym bardziej zwiększa prawdopodobieństwo występowania tej samej reakcji przy innym zespole bodźców,

a) im większe jest podobieństwo między tymi dwoma zespołami bodźców; 
b) im większa jest siła motywacji skłaniającej do danej reakcji;

c) im rzadziej osobnik stykał się z sytuacjami, w których ta sama reakcja przy jednym układzie bodźców była nagradzana, a przy innym podobnym układzie bodźców nie była nagradzana lub była karana" 6 .

Przytoczone twierdzenia stanowią zarazem wykładnię podstaw terapii behawioralnej, która w sposób szczególny zadomowiła się w pedagogice resocjalizacyjnej, zwłaszcza jednak w jej wymiarze teoretycznym i w nieco bardziej ograniczonym zakresie w wymiarze praktycznym. Nabrało to zresztą szczególnego wyrazu w naszym rodzimym, pierwszym podręczniku Pedagogiki resocjalizacyjnej autorstwa Czesława Czapówa i Stanisława Jedlewskiego 7 . Zasadniczo ukształtował on polską teorię i praktykę postępowania opiekuńczego, terapeutycznego oraz wychowawczego wobec osób niedostosowanych społecznie i wykolejonych przestępczo. Po dzisiejszy dzień stanowi on o specyfice tej dyscypliny wiedzy i praktyki, budowanej zasadniczo na podstawach teorii uczenia się, odnoszonych równocześnie do ujmowanych z perspektywy psychologii dynamicznej procesów motywacyjnych, emocjonalnych i poznawczych, a także do teorii socjalizacji i twórczej samodzielności ${ }^{8}$. Zapewne też $\mathrm{z}$ tego względu w polskiej tradycji teoria i praktyka oddziaływania poprawczo-wychowawczego i terapeutycznego wobec osób wykolejonych społecznie i przestępczo zadomowiła się w obszarze pedagogiki pod nazwą właśnie pedagogiki resocjalizacyjnej. Ten sam obszar wiedzy i praktyki, uprawiany zresztą z podobnej perspektywy teoretycznej, w społeczeństwach zachodu częściej nazywany bywa jako postępowanie rehabilitacyjne, korekcyjne (rehabilitation,

${ }^{6}$ A. Malewski, O nowy ksztatt nauk społecznych. Pisma zebrane, PWN, Warszawa 1975, s. 382-385. s. 535 .

${ }^{7}$ C. Czapów, S. Jedlewski, Pedagogika resocjalizacyjna, PWN, Warszawa 1971,

${ }^{8}$ W. Kaczyńska, Pedagogika resocjalizacyjna Czesława Czapówa. Ku „antropologii praktycznej", [w:] W. Kaczyńska (oprac. i red.), Czesław Czapów 1925-1980. Świadectwa trzech pokoleń, Instytut Profilaktyki Społecznej i Resocjalizacji UW, Warszawa 2003, s. 365-366. 
correction), readaptacyjne, reintegracyjne itp. i mieści się bardziej w obszarze współczesnej teorii oraz praktyki pracy socjalnej niż teoretycznych i praktycznych koncepcji uprawiania pedagogiki. Nie ma to jednak większego wpływu na kształt uprawianej, zwłaszcza z perspektywy behawioralnej, koncepcji postępowania korekcyjno-resocjalizacyjnego wobec nieletnich i dorosłych przestępców czy też osób przejawiających rozmaite inne niepożądane społecznie zachowania. Dominuje tu - zwłaszcza w odniesieniu do nieletnich przestępców - podejście określane mianem systemu progresywnego, występujące współcześnie częściej pod nazwą „ekonomii punktowej” (token economy). Powstały bowiem jakby w opozycji do tradycyjnego systemu dyscyplinarno-izolacyjnego, przenikającego zasadniczo wszystkie płaszczyzny funkcjonowania systemu resocjalizacyjnego, a w pewnym sensie i w opozycji do równie restrykcyjnego systemu wychowania model oddziaływania progresywnego zrywał zasadniczo z dominującą praktyką dyscyplinującego karania i izolowania głównie nieletnich, ale również dorosłych przestępców poddawanych zwłaszcza oddziaływaniu zamkniętych placówek wychowawczo-poprawczych, względnie zakładów karnych. Istotą systemu progresywnego było przede wszystkim to, że opierał się on na precyzyjnie określonym wykazie nagród, które zdobywane przez wychowanków powodowały ich przechodzenie z grup o ograniczonej liczbie przywilejów do grup o coraz większej ich liczbie i zakresie. Ukoronowaniem owych przywilejów i zarazem wskaźnikiem zaistniałej poprawy w zachowaniu były grupy półwolnościowe, umieszczane często poza zakładem zamkniętym, gdzie wychowankowie już tylko przy znacznie ograniczonym dozorze podejmowali w miarę samodzielne życie, naukę lub pracę ${ }^{9}$. W polskich warunkach zwłaszcza w latach sześćdziesiątych i siedemdziesiątych ubiegłego stulecia - był to rodzaj internatów lokowanych przy zakładach przemysłowych, do których owa grupa półwolnościowa była przypisana, pozostając $\mathrm{w}$ dalszym ciągu strukturą macierzystego zakładu poprawczego. $W$ innych krajach grupy te przybierały przykła-

${ }_{9}$ Patrz: C. Czapów, S. Jedlewski, dz. cyt., s. 467-468. 
dowo postać mieszkań socjalnych lokowanych poza macierzystą placówką, gdzie usamodzielniani wychowankowie zamieszkiwali i pod dyskretną opieką wychowawczą podejmowali samodzielne życie. Jako przykład ilustrujący wykorzystywanie w praktyce systemu progresywnego mogą posłużyć rozmaite formy hosteli stanowiących ogniwo pośrednie pomiędzy więzieniem a pełnym uwolnieniem. Tam osoby kończące odbywanie kary pozbawienia wolności albo już zwolnione przechodzą okres próby lub stopniowo, jeszcze z pomocą placówki penitencjarnej, wchodzą w życie na wolności. Taki też projekt hosteli powstał przy okazji reformy pozostających w dyspozycji Ministerstwa Sprawiedliwości zakładów poprawczych w roku 1997, jednak nigdy nie został wdrożony do praktyki10. Wreszcie, przykładem wykorzystywania pewnych elementów systemu progresywnego jest stosowana powszechnie, nie tylko zresztą w naszym więziennictwie, praktyka udzielania nagród za dobre sprawowanie w postaci dodatkowych wypisek, widzeń, urlopów itp. czy też opisane w literaturze przykłady rozwiązań eksperymentalnych realizowanych na przykład w Zakładzie Karnym w Gdańsku-Przeróbce ${ }^{11}$, zakładach karnych w Rzeszowie i w Nysie12, Oddziale Zewnętrznym Aresztu Śledczego w Radomiu'13.

W systemie progresywnym, mimo że preferowano pozytywne wzmocnienia w postaci nagród, to również stosowano kary, które skutkowały cofaniem uzyskanych przywilejów aż do ponownego osadzenia w grupie o niższym statusie uprawnień włącznie. W spo-

10 Por. przykładowo A. Barczykowska, Halfway houses - między więzieniem a wolnościa, [w:] A. Kieszkowska (red.), Tożsamość osobowa dewiantów a ich reintegracja społeczna, Oficyna Wydawnicza „Impuls”, Kraków 2011, s. 223-240, a także patrz Raport o stanie wdrażania reformy resocjalizacji w zakładach poprawczych, L. Pytka (red.), Ministerstwo Sprawiedliwości, Departament Spraw Rodzinnych i Nieletnich, Warszawa 1998.

${ }^{11} \mathrm{H}$. Machel, Więzienie jako instytucja karna i resocjalizacyjna, Arche, Gdańsk 2003, s. 43-44.

12 J. Rejman, System wychowawczy zakładu penitencjarnego dla młodocianych. Model organizacyjny i resocjalizacyjny, Wyd. Wyższej Szkoły Pedagogicznej, Rzeszów 2000.

${ }^{13}$ P. Baziak, Recydywiści w zakładzie karnym. Nowe rozwiąania, [w:] W. Kaczyńska (oprac. i red.), Czestaw Czapów 1925-1980. Świadectwa trzech pokoleń, Instytut Profilaktyki Społecznej i Resocjalizacji, Warszawa 2003, s. 315-331. 
sób szczególnie wyrazisty zasady progresji, zwłaszcza nagród, ale również kar, oddawała metoda ekonomii punktowej czy też żetonowej powszechnie stosowana w placówkach resocjalizacyjnych, szczegółowo opisana przez K. Pospiszyla w przywoływanej pracy. Przedstawione przez autora różne odmiany tej metody sprowadzają się zasadniczo do nagradzania wychowanków punktami lub żetonami za ustalone przejawy pozytywnego zachowania się i równoczesnego pozbawiania wychowanków tych nagród w sytuacji pojawienia się zachowań nagannych. Uzyskane punkty czy żetony wychowankowie mogli wymieniać na różne rzeczy wartościowe albo nawet na obiegową walutę, za którą mogli następnie nabywać określone towary, usługi (np. ubezpieczenia zdrowotne), zaciągać kredyty itp. Istniały również systemy ekonomii punktowej w sposób szczególny preferujące aktywność edukacyjną związaną z uzupełnianiem zaniedbanego wykształcenie lub z podnoszeniem swoich kwalifikacji zawodowych ${ }^{14}$.

System progresywny niósł także rozmaite zagrożenia, z których najczęściej wymienia się pozorowane, czysto zewnętrzne, przystosowanie się wychowanków do ustanowionych norm, podejmowanie aktywności tylko w sytuacji, kiedy przynosi ona opłacalną premię, co nieuchronnie prowadzi do swoistej specjalizacji w przejawianiu ściśle określonych aktywności, wreszcie brak elastyczności w uwzględnianiu indywidualnych cech wychowanków, co przyczynia się najczęściej do małej skuteczności stosowanych wzmocnień czy kar, a także sprowadza rolę wychowawcy jedynie do zewnętrznego obserwatora i arbitra przydzielającego odpowiednie nagrody czy kary, niewchodzącego w bliższe interakcje wychowawcze. W tym właśnie względzie rola wychowawcy w systemie progresywnym właściwie niczym nie różni się od roli, jaką przypisuje mu się w systemie dyscyplinarno-izolacyjnym ${ }^{15}$.

14 Szczegółowe przykłady stosowania ekonomii punktowej patrz K. Pospiszyl, dz. cyt., s. 102-134.

${ }^{15}$ Por. także C. Czapów, S. Jedlewski, dz. cyt., s. 468 oraz R. Opora, Ewolucja niedostosowania społecznego jako rezultat zmian w zakresie odporności psychicznej $i$ zniekształceń poznawczych, Wyd. Uniwersytetu Gdańskiego, Gdańsk 2009, s. 58. 
Ukazane do tej pory przykłady zastosowania koncepcji behawioralnych $\mathrm{w}$ resocjalizacji odnosiły się głównie do instytucji wychowawczych czy poprawczych przeznaczonych dla nieletnich, charakteryzujących się niedostosowaniem społecznym bądź wykolejeniem przestępczym. Obecność koncepcji behawioralnych w praktyce resocjalizacji osób dorosłych jest niewątpliwie rzadsza, co wydaje się wypływać z tego, że subsystemy te bardziej zdominowane zostały przez prawnokryminologiczne koncepcje kary niż przez rozwijające się coraz bardziej, począwszy od czasów nowożytnych, psychologiczno-pedagogiczne wizje postępowania korekcyjno-uspołeczniającego $\mathrm{z}$ osobami niedostosowanymi społecznie $\mathrm{i}$ wykolejonymi przestępczo. Do rozdzielenia się tych systemów niewątpliwie przyczyniły się, rozwijające się coraz bardziej od epoki odrodzenia, koncepcje resocjalizacyjne nakazujące odmiennie traktować nieletnich i młodocianych przestępców oraz równocześnie rozdzielać funkcjonujące wobec nich systemy instytucjonalne. O ostatecznym jednak rozejściu się tych systemów zadecydowały, rozwijające się coraz bardziej od XIX stulecia, idee pajdocentryzmu, a później także pedagogiki specjalnej. $W$ tych to nurtach i dziedzinach koncepcje resocjalizacji nieletnich przejawiających zachowania świadczące o ich niedostosowaniu społecznym bądź wykolejeniu przestępczym natrafiły na sprzyjający rozwojowi grunt. Od tego też okresu subsystemy resocjalizacji nieletnich i dorosłych rozwijały się zarówno koncepcyjnie, jak i organizacyjnie oddzielnie, co miało konsekwencje w tym, że stosowne pedagogiczne czy psychologiczne idee wychowania poprawczo-uspołeczniającego trafiały $\mathrm{w}$ obszar resocjalizacji osób dorosłych przestępców ze znacznym oporem i opóźnieniem. Tak też ma się sprawa $\mathrm{z}$ obecnością koncepcji behawioralnych w resocjalizacji penitencjarnej dorosłych. Błędem bowiem dzisiejszych koncepcji resocjalizacji dorosłych budowanych na podstawach behawioralnych jest to, że próbują one w dość prosty sposób przenosić sam proces uczenia się nieletnich jako podstawowy mechanizm ich resocjalizacji na grunt jednak odmiennie toczącego się tego mechanizmu w przypadku resocjalizacji dorosłych. Różnica ta wynika choćby z tego faktu, że uczenie się osób dorosłych bardziej 
pozostaje „kombinacją procesów, w trakcie których osoby te konstruują swoje doświadczenia sytuacyjne [nabyte zresztą $w$ licznych i rozmaitych kontekstach społeczno-kulturowych - przyp. W.A.] oraz przekształcają je $\mathrm{w}$ wiedzę, umiejętności, postawy, przekonania, wartości, emocje, sensy i znaczenia oraz integrują je w obrębie własnej biografii"16. Praktyka instytucjonalnych oddziaływań resocjalizacyjnych wobec dorosłych pozostaje jednak $\mathrm{w}$ tym względzie dość powierzchowna i prymitywna we wzmacnianiu zachowań pożądanych i oczekiwanych społecznie. $W$ codzienności działania i w skali masowej rolę tę najczęściej spełniają wspomniane już regulaminowe nagrody. Przybierają one postać przepustek, urlopów, wypisek umożliwiających zakupy w więziennej kantynie itp., co oczywiście stanowi dość ograniczony wachlarz oddziaływań stymulujących osadzonych do zachowań pożądanych, często wykalkulowanych i nakierowanych na osiągnięcie zaplanowanych korzyści czy potrzeb, zupełnie natomiast nieoddziaływujących na osobowość skazanych. $Z$ równie podobnym skutkiem próbowano wdrażać do praktyki penitencjarnej z dorosłymi system progresywny, który dość powszechnie przyjęty został przez więziennictwo europejskie w okresie międzywojennym ubiegłego stulecia. Jego celem podobnie jak $\mathrm{w}$ przypadku nieletnich - było przygotowanie skazanych do życia na wolności poprzez stopniowe łagodzenie rygorów odbywania kary pozbawienia wolności ${ }^{17}$. Pewne relikty wspomnianego systemu można jeszcze zaobserwować $\mathrm{w}$ wielu działających w poszczególnych narodowych systemach penitencjarnych typach zakładów karnych (czy też działających w nich oddziałów) mających na celu dostosowanie sposobu wykonywania kary pozbawienia wolności do indywidualnych cech skazanych, co w konsekwencji pociąga za sobą tworzenie zakładów o rozmaitych metodach

${ }^{16}$ P. Jarvis, Adult Education and Lifelong Learning. Theory and Praktice, Routledge-Flamer, London-New York 2004, s. 111, cyt. za: M. Malewski, Od nauczania do uczenia się. O paradygmatycznej zmianie w andragogice, Wyd. Nauk. Dolnośląskiej Szkoły Wyższej, Wrocław 2010, s. 104.

${ }_{17}$ Patrz: M. Ciosek, Psychologia sądowa i penitencjarna, wyd. 2., Wyd. Prawnicze LexisNewis, Warszawa 2003, s. 189-192. 
i reżimach oddziaływania oraz do konieczność odpowiedniego klasyfikowania samych skazanych.

Również w naszym obecnym systemie więziennictwa spotkać można rozmaite eksperymentalne próby stosowania systemu progresywnego, istotnie zresztą wzbogacające jego klasyczną postać i przystosowujące jego formę do naszych rodzimych warunków. Jako przykład może tu posłużyć wdrażany w latach 1980-1981 w Zakładzie Karnym w Gdańsku-Przeróbce autorski model H. Machela, ówczesnego naczelnika tamtejszego więzienia, a obecnie profesora pedagogiki Uniwersytetu Gdańskiego, niwelującego dystans sprzeczności pomiędzy funkcję karną i izolacyjną więzienia a jego funkcją korekcyjną i resocjalizacyjną. Tworzone w tym modelu trzy różniące się uprawnieniami więźniów rygory odbywania kary realizowały znaną zasadę progresji uprawnień i przywilejów w ślad za osiąganymi postępami w resocjalizacji. W najbardziej złagodzonym rygorze działał samorząd więźniów i mąż zaufania, które to ogniwa miały istotny wpływ na przyznawanie więźniom przewidzianych regulaminem przywilejów. Wszystko to miało na celu budowanie partnerskich relacji między personelem a skazanymi, którzy czynnie współuczestniczyli w procesie resocjalizacji współwięźniów i ponosili odpowiedzialność za jego skutki. Ważnym elementem tego modelu było świadczenie przez więźniów pracy, również poza więzieniem i bez dozoru, a także częste kontakty więźniów z rodzinami, bądź poprzez stosowany system przepustek, bądź poprzez udział rodzin i najbliższych w rozmaitych imprezach organizowanych na terenie więzienia. Praca poza więzieniem oraz kontakty skazanych $\mathrm{z}$ rodzinami miały $\mathrm{w}$ znaczący sposób kompensować skutki uwięzienia. Oczywiście nie wszystkie kategorie osadzonych mogły, czy też gotowe były, w niniejszym eksperymencie uczestniczyćc ${ }^{18}$.

Innym równie interesującym przykładem stosowania modelu resocjalizacji behawioralnej osób dorosłych był realizowany w latach 1991-1997 przez B. Jarzębowską-Baziak autorski program trak-

18 Patrz szczegóły: H. Machel, dz. cyt., s. 43-44. 
towania regresywnego recydywistów w Oddziale Zewnętrznym Aresztu Śledczego w Radomiu. Jego istotą było, aby źródłem wzmocnień uczynić nie regulaminowe nagrody, a przejawianą przez skazanych recydywistów własną aktywność i dokonywane wybory, czyniąc ich równocześnie odpowiedzialnymi za te aktywności. Skazanym stopniowo poszerzano zakres upodmiotowienia, organizowano sytuacje stymulujące stosowne aktywności i przejawy samodzielności, a także umożliwiające zdobycie nowych doświadczeń czy skorygowanie już utrwalonych przekonań, zasad postępowania lub wartości. Oddziaływaniom tym towarzyszyły rozmaite formy wzbogacania wiedzy i poszerzania kompetencji oraz eliminowania istniejących deficytów. Udział w programie nadawał skazanym szereg uprawnień (np. korzystanie w własnej odzieży, posiadanie pieniędzy i dysponowanie nimi, nielimitowana liczba odwiedzin, możliwość kształcenia się poza więzieniem, przywilej zatrudnienia poza zakładem, korzystanie z wyjść zadaniowych itp.), a także pociągał za sobą konieczność podjęcia stosownych oddziaływań wobec rodzin skazanych. Wstępne wyniki badań nad efektywnością tego programu potwierdziły jego skuteczność przejawiającą się w postaci pomyślnej readaptacji do warunków życia na wolności, wyrażającej się między innymi stosunkowo niskim wskaźnikiem powrotności do przestępstwa ${ }^{19}$.

Tego typu prób i eksperymentów w polskim więziennictwie było oczywiście znacznie więcej. Warto tu chociażby przywołać przykład słynnego eksperymentu W. i H. Świdów, prowadzonego w nieistniejącym już Zakładzie Karnym w Szczypiornie, koncepcję systemu ocen punktowych J. Rejmana realizowaną w zakładach karnych w Nysie i Rzeszowie, wreszcie opolską koncepcje oddziałów wewnętrznych J. Koreckiego itp. ${ }^{20}$ Przytoczone przykłady nie wyczer-

${ }^{19}$ Por. P. Baziak, Recydywiści w zakładzie karnym. Nowe rozwiązania, [w:] W. Kaczyńska (red.), Czestaw Czapów 1925-1980. Świadectwa trzech pokoleń, Instytut Profilaktyki Społecznej i Resocjalizacji UW, Warszawa 2003, s. 315-331.

${ }^{20}$ H.W. Świda, Młodociani przestępcy w więzieniu, Książka i Wiedza, Warszawa 1972; J. Korecki, Opolska koncepcja usprawnienia wewnętrznej struktury i funkcjonowania dużych zakładów karnych poprzez wyodrębnienie tzw. „oddziałów wewnętrznych”, [w:] 
pują rzecz jasna obfitości i rozmaitości stosowanych programów terapii behawioralnej w placówkach resocjalizacji nieletnich i dorosłych przestępców. Ich obfitość i rozmaitość nie świadczą jednak o powszechności ich stosowania oraz o strukturalnym i funkcjonalnym przeniknięciu koncepcji behawioralnej do całego systemu resocjalizacji. Stanowią one jedynie przykład wielorakich, najczęściej oddolnych, prób przełamywania tradycyjnego podejścia do procesu resocjalizacji przestępców. Jednak, mimo dość powszechnej krytyki, w dalszym ciągu bardziej tkwi on w prawnokryminologicznych niż w psychologiczno-pedagogicznych koncepcjach kary i ona też decyduje o kształcie oraz przebiegu całego procesu resocjalizacji.

\section{Bibliografia}

BARCZYKOWSKA A., Halfway-houses - między więzieniem a wolnościa, [w:] A. Kieszkowska (red.), Tożsamość osobowa dewiantów a ich reintegracja spoteczna, Oficyna Wydawnicza „Impuls”, Kraków 2011, s. 223-240.

BAZIAK P., Recydywiści w zakładzie karnym. Nowe rozwiazania, [w:] W. Kaczyńska (oprac. i red.), Czestaw Czapów 1925-1980. Świadectwa trzech pokoleń, Instytut Profilaktyki Społecznej i Resocjalizacji UW, Warszawa 2003, s. 315-331.

CIOSEK M., Psychologia sadowa i penitencjarna, wyd. II, Wyd. Prawnicze LexisNewis, Warszawa 2003.

CZAPÓW C., JEDLEWSKI S., Pedagogika resocjalizacyjna, PWN, Warszawa 1971.

HURRELMANN K., Struktura społeczna a rozwój osobowości, Wyd. Nauk. UAM, Poznań 1994.

KACZYŃSKA W., Pedagogika resocjalizacyjna Czestawa Czapówa. Ku antropologii praktycznej, [w:] W. Kaczyńska (oprac. i red.), Czestaw Czapów 1925-1980. Świadectwa trzech pokoleń, Instytut Profilaktyki Społecznej i Resocjalizacji UW, Warszawa 2003, s. 355-388.

KORECKI J., Opolska koncepcja usprawniania wewnętrznej struktury i funkcjonowania dużych zakładów karnych przez wyodrębnienie tzw. "oddziałów wewnętrznych", [w:] W. Ambrozik, P. Stępniak (red.), Problemy organizacji i zarzadzania więzieniem, COSSW, Poznań-Kalisz-Warszawa 1999, s. 292-302.

MACHEL H., Więzienie jako instytucja karna i resocjalizacyjna, Arche, Gdańsk 2003.

W. Ambrozik, P. Stępniak (red.), Problemy organizacji i zarządzania więzieniem, COSSW, Poznań-Kalisz-Warszawa 1999, s. 292-302; J. Rejman, cyt. dz. 
MALEWSKI A., O nowy kształt nauk społecznych. Pisma zebrane, PWN, Warszawa 1975.

MALEWSKI M., Od nauczania do uczenia się. O paradygmatycznej zmianie w andragogice, Wyd. Nauk. Dolnośląskiej Szkoły Wyższej we Wrocławiu, Wrocław 2010.

OPORA R., Ewolucja niedostosowania społecznego jako rezultat zmian w zakresie odporności psychicznej i znieksztatceń poznawczych, Wyd. Uniwersytetu Gdańskiego, Gdańsk 2009.

POSPISZYL K., Resocjalizacja. Teoretyczne podstawy oraz przykłady programów oddziaływania, Wyd. Akademickie „Żak”, Warszawa 1998.

PYTKA L., Pedagogika resocjalizacyjna. Wybrane zagadnienia teoretyczne, diagnostyczne i metodyczne, Wyd. Akademii Pedagogiki Specjalnej, Warszawa 2000.

Raport o stanie wdrażania reformy resocjalizacji w zakładach poprawczych, L. Pytka (red.), Ministerstwo Sprawiedliwości, Warszawa 1998.

REJMAN J., System wychowawczy zakładu penitencjarnego dla młodocianych. Model organizacji i resocjalizacji, Wyd. WSP, Rzeszów 2000.

ŚWIDA H.W., Młodociani przestępcy w więzieniu, Książka i Wiedza, Warszawa 1972.

URBAN B., Pedagogika resocjalizacyjna w strukturze nauk społecznych, [w:] S. Palka (red.), Pogranicza pedagogiki i nauk pomocniczych, Wyd. Uniwersytetu Jagiellońskiego, Kraków 2004, s. 165-182.

URBAN B., Zaburzenia w zachowaniu i przestępczość młodzieży, Wyd. Uniwersytetu Jagiellońskiego, Kraków 2000. 